\title{
Impact of Encroachment and Hyderabad City Effluents on Pinyari Canal
}

\author{
Ali Asghar Mahessar \\ Sindh Barrages Improvement Project \\ Irrigation Department, Government of Sindh \\ Karachi, Pakistan
}

Abdul Latif Qureshi

USPCAS-W

Mehran University of Engineering and Technology Jamshoro, Pakistan

Ashafaque Pathan

Department of Civil Engineering

Mehran University of Engineering and Technology

Jamshoro, Pakistan

\author{
Kamran Ansari \\ USPCAS-W \\ Mehran University of Engineering and Technology \\ Jamshoro, Sindh, Pakistan
}

Kishan Chand Mukwana

Department of Energy and Environment Engineering

Quaid-e-Awam University of Engineering, Science and

Technology, Nawabshah, Pakistan

\author{
Shafi Muhammad Kori \\ Department of Civil Engineering \\ Mehran University of Engineering and Technology \\ Jamshoro, Pakistan
}

\begin{abstract}
Pinyari canal off-takes from the left bank of Kotri barrage with a design discharge of 13,636 cusecs which passes through the ridge of Hyderabad city along with New Fuleli Canal and Akram Wah on its left side. Its water is used for irrigation, agriculture, industrial, domestic, and drinking purposes in Hyderabad and Sajawal districts in Sindh. This canal is nonperennial. Water is being released with low discharge only for drinking purposes during the dry season and with full supply in the wet season. The global water quality issue reflects the major impact of socioeconomic development and population growth changes on freshwater resources including canals and rivers. This paper presents the impact of untreated wastewater disposal to the canal. The practice of disposing of untreated effluents has created serious health and environmental problems for the locals. The statistical and geospatial tool GIS has been used for the assessment of water quality with visualization of wastewater behavior in the canal. The results of the statistical analysis showed that $\mathbf{p H}$ was within the permissible limits but Electric Conductivity (EC), Total Dissolved Solids (TDS), Sodium (Na), and Hardness exceed them. The Water Quality Index of the samples rated from very poor to unsuitable for drinking, hence, canal water is unfit for domestic use or drinking purposes.
\end{abstract}

Keywords-waterborne diseases; Hyderabad city; solid waste; wastewater; GIS; statistics

\section{INTRODUCTION}

Globally, freshwater resources are depleting and their quality is deteriorating due to over exploitation. Effluents from various sources are discharged into freshwater bodies and rivers creating potential risks for public health $[1,2]$. Furthermore, the growing population with economic development poses a pressure on the available limited freshwater resources. Waste disposal has created critical problems to the environment $[3,4]$. The water quality of the rivers in Pakistan has been degraded due to wastewater discharge $[5,6]$. The rivers and canals have directly been contaminated from industrial and urban waste of major cities [7]. The discharge of wastewater from the industries is most alarming in rivers, canals, and drains irrespective of wastewater treatment. Karachi, Sialkot, Faislabad and Lahore cities are major contributors of pollution into fresh water bodies [8]. Polluted water from urban and industrial sources has been disposed to urban peripheral canals. Hence, municipal, domestic, industrial, and agricultural waste, animal manure, etc. are dumped directly to canals [9]. Sewage water is added to canals by different sources of drains which affects directly their water quality $[10,11]$.

The consumption of contaminated fresh canal water poses negative impacts on public health and agro-environment [12]. The reuse of wastewater has a potential in industrializing countries as being cost-effective for industries where secondary effluents are readily available for reuse [13]. Annually, about 1.8 million people die from waterborne diseases from the consumption of contaminated water $[14,16]$ and frequent attacks of diarrhea caused by bad water quality can leave a child more vulnerable to illness [6]. Recent studies indicate that the various water quality parameters of Pakistan drinking water do not meet the Standards of Pakistan and WHO [15]. Various researchers have indicated that fresh water quality in several countries is not in accordance with WHO standards [17]. However, the introduction of remote sensing technology and of the Geographical Information System (GIS) has made easy to integrate various metadata for assessment of water quality and gave a powerful tool for mapping and assessing water quantity and quality, flood management, and precipitation assessment

Corresponding author: Ali Asghar Mahessar (amahessar@yahoo.com) 
$[18,19]$. The Remote Sense is a useful tool to classify LC and LU changes with various datasets. Meanwhile, the Water Quality Index (WQI) which is used globally for water quality assessment is the most operative model for management and evaluation of surface and groundwater quality $[14,20]$. Thus, the aim of this study is to explore the eco-chemical status of water quality of the Pinyari canal which is degraded by the disposal of effluents from Hyderabad city and the encroached canal banks area.

\section{STUDY AREA}

Hyderabad city is located at the left side of Indus River and its population is about 1.5 million residing in the urban area comprised on Talukas such as Qasimabad, Latifabad, Cantonment, and Hyderabad city as shown in Figure 1(a). This dense populated city has a drainage system with wastewater treatment plants but no safe disposal points, thus the wastewater of the entire city is directly or indirectly disposed to the canals. The wastewater treatment plants are almost dysfunctional and not in accordance with modern technology. Water samples were collected at different wastewater disposal locations as shown in Table I and Figure 1(b). This study has been conducted considering encroachment, dumping of solid waste, disposal of waste water into canals from the head regulator of the canal to Hosri town covering a distance of $30 \mathrm{Km}$ as shown in Figure 2.

(a)

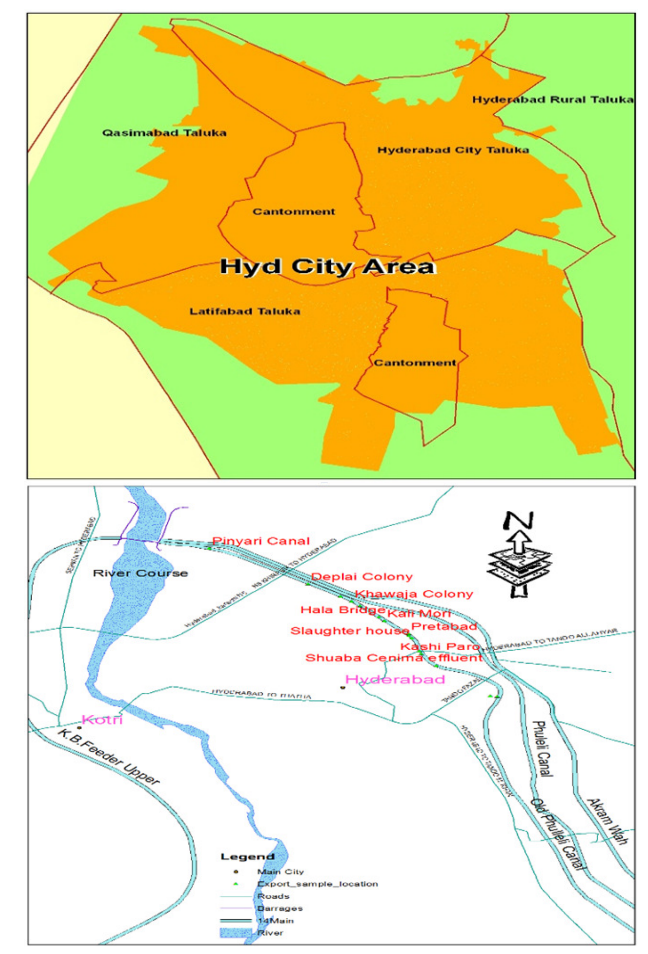

Fig. 1. (a) Study area, (b) disposal and sample collection locations

\section{MATERIALS AND METHODS}

\section{A. Sampling}

A survey was conducted in the study area regarding encroachment (i.e. the existence of illegal permanent buildings such as households, farms or factories), major disposal locations from the city, and industrial units. Figure 2 shows the encroached left and right banks of the canal with houses, huts, ranches, and farms with high density. The solid waste and wastewater is directly dumped to the canal. There are many major and small inlets for wastewater disposal to the canal at locations such as the Deplai Colony wastewater pumping station, the Jacob wastewater pumping station, the wastewater of Khawja colony, the outfall structure at Kari Mori bridge, the outfall structure just upstream the railway line, and the Darya Khan pumping station (Figure 2). Samples were collected and preserved in an icebox in $4^{\circ} \mathrm{C}$. Nitric acid $\left(\mathrm{HNO}_{3}\right)$ was added to the sampling bottles in quantities sufficient to lower the $\mathrm{pH}$ of the sample to just about 2 , to stabilize the concentration of total and dissolved metals for a maximum of 28 days. Standard sample transfer procedures were followed to avoid confusion in sample identification, including labeling and safe transportation to laboratory. The collected samples were sent to the Hi Tech Laboratory of the Sindh University, for further analysis.

TABLE I. SAMPLE COLLECTION LOCATIONS

\begin{tabular}{|c|c|c|c|}
\hline Sample \# & Latitude & Longitude & Location \\
\hline 1 & $25^{\circ} .44339$ & $68^{\circ} .37372$ & $\begin{array}{c}\text { Hur Camp pumping station wastewater } \\
\text { dumping into the canal }\end{array}$ \\
\hline 2 & $25^{\circ} .43706$ & $68^{\circ} .38622$ & Wastewater of Khawaja colony \\
\hline 3 & $25^{\circ} .40994$ & $68^{\circ} .38989$ & $\begin{array}{c}\text { Wastewater dumping from the central jail } \\
\text { area into the canal. }\end{array}$ \\
\hline 4 & $25^{\circ} .42556$ & $68^{\circ} .37939$ & Hala Road bridge \\
\hline 5 & $25^{\circ} .43178$ & $68^{\circ} .38383$ & $\begin{array}{c}\text { Wastewater into the canal, just d/s of Kari } \\
\text { Mori }\end{array}$ \\
\hline 6 & $25^{\circ} .415$ & $68^{\circ} .39122$ & Wastewater into the canal just d/s of \\
Preatabad bridge
\end{tabular}

\section{B. Water Quality Index (WQI)}

WQI is an indicator of water suitability for drinking and surmises many parameters [21]. The equation of WQI is:

$$
Q W I=\sum_{1}^{n} W_{i} \times Q_{i}
$$

where $Q_{i}$ is the $i^{\text {th }}$ WQ parameter, $W_{i}$ is the weight associated with this parameter, and $n$ is the total number of WQ parameters. The classification of water samples according to the WQI is shown in Table II.

TABLE II. WQI RATINGS

\begin{tabular}{|c|c|}
\hline WQI value & Rating \\
\hline $0-25$ & Excellent \\
\hline $25-50$ & Good \\
\hline $50-75$ & Poor \\
\hline $75-100$ & Very poor \\
\hline$>100$ & Unsuitable for drinking \\
\hline
\end{tabular}




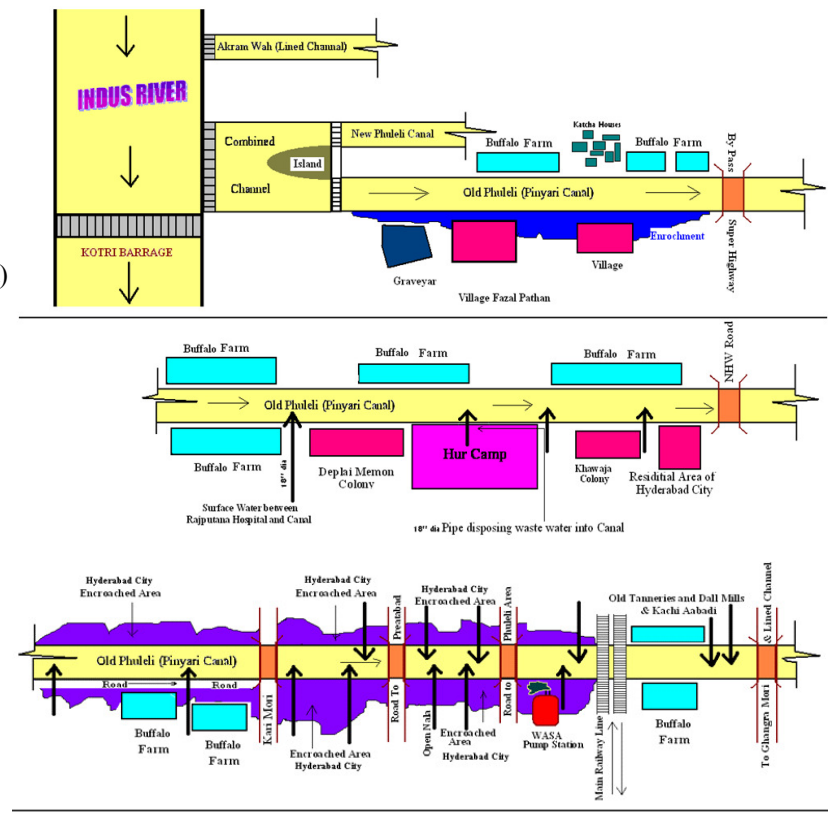

(b)

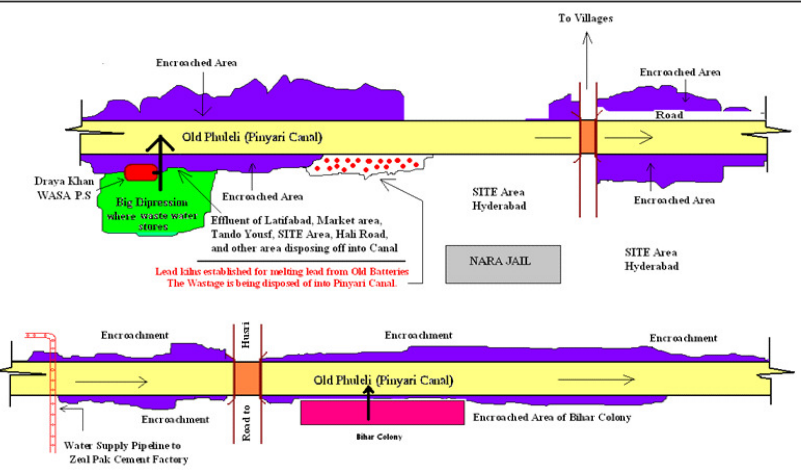

(c)

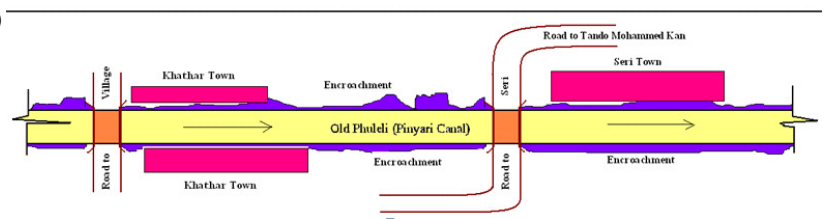

Fig. 2. Solid waste dumping and wastewater disposal to the Pinyari canal

\section{RESULTS AND DISCUSSION}

\section{A. Solidwaste Dumping}

Besides the problem of wastewater discharging, a huge volume of solid waste is dumped to the canal. Solid waste dumping locations along the canal were observed during the survey at Hala road bridge, Kari Mori bridge, downstream of the Pretabad bridge, adjacent to the slaughterhouse, and at the railway bridge. The estimated quantity of solid waste on the canal embankments is about 15-20 tons per day (Figure 2).

\section{B. Buffaloe Farms (BFs) on the Banks of Pinyari Canal}

Many BFs were spotted during sampling, i.e. 4 on the left side of the canal just upstream of the bypass bridge, each farm with 15 to 40 buffaloes and 6 BFs on the right side of the canal just upstream of the Bypass bridge, with 10-35 buffaloes, 8
BFs on the left side of the canal between the bypass road bridge and Hala road bridge, with 10-25 buffaloes, and $10 \mathrm{BFs}$ between the bypass road bridge and the Hala Road bridge with 10-30 buffaloes on the right side of the canal (Figure 2). The manure and the other waste of the farms are directly disposed to the canal.

\section{City Wastewater}

- Deeplai Colony wastewater pumping station is discharging its wastewater into the canal at RD $14+00$ and has a capacity of about 7.8 million gallons per day.

- Pumping Station at Jacob Ponds is pumping wastewater at RD 16+00 through a delivery pipe with 18 " diameter.

- Wastewater of Khawja/Mubark Colony discharges wastewater into the canal at RD $17+00$ and $18+00$ by pipes and the estimated disposal water is about 0.6 million gallons per day.

- Outfall Structures at Kari Mori Bridge. The effluent of vast area of Market and Hirabad area is being discharged through these inlets at RD $24+00$. An open channel of 6' $\times 6$ ' just downstream of Kari Mori Bridge is discharging 10 to 15 cusecs of untreated wastewater.

- Slaughterhouse: the wastewater of the Liaquat colony and the slaughterhouse is being disposed of at RD $25+00$. The main slaughterhouse is situated downstream of Pretabad bridge on the right bank which is a covered large area in which an estimated number of 1500 animals are being slaughtered every day. The remains and the blood are directly dumped to the canal.

- Outfall structure upstream of railway bridge: The main outfall structure and pumping station on the right side of the canal and near the railway bridge has been constructed by Hyderabad Development Authority (HDA) for discharging wastewater at RD $28+00$.

- Darya Khan pumping station: Darya Khan wastewater outfall and pumping station is situated at RD $40+00$ on the right side of the canal has been constructed by HDA and receives untreated wastewater of Hyderabad SITE area. During the dry season when there is not water available in the canal, the wastewater is being discharged through gravitational flow, whereas during the full supply flow in canal the wastewater is discharged through pumping.

There are 17 main and about 20 small locations inlets on the left side of the canal from where the untreated wastewater generated from small industries and municipal areas is being discharged. There are 20 main and many small inlets at the right side of the canal from where the untreated wastewater is being discharged. The total estimated discharge of untreated wastewater (industrial \& municipal) into the canal is about 90 million gallons per day.

\section{Canal Wastewater Sample Analysis}

The collected samples were analyzed at the $\mathrm{Hi}$ Tech Laboratory of Sindh University. The results are shown in Table II and are discussed below. 


\section{1) $p H$}

It is a measure of the acidic or basic (alkaline) nature of a solution. A pH ranging from 6.5 to 8.5 is suitable for aquatic life. It was observed after analyzing of the samples that the values of all samples ranged from 6.5 to 7.3 , hence $\mathrm{pH}$ is within the permissible limits of NEQS (Table III). Figure 3 exhibits the geospatial distribution of $\mathrm{pH}$ using GIS.

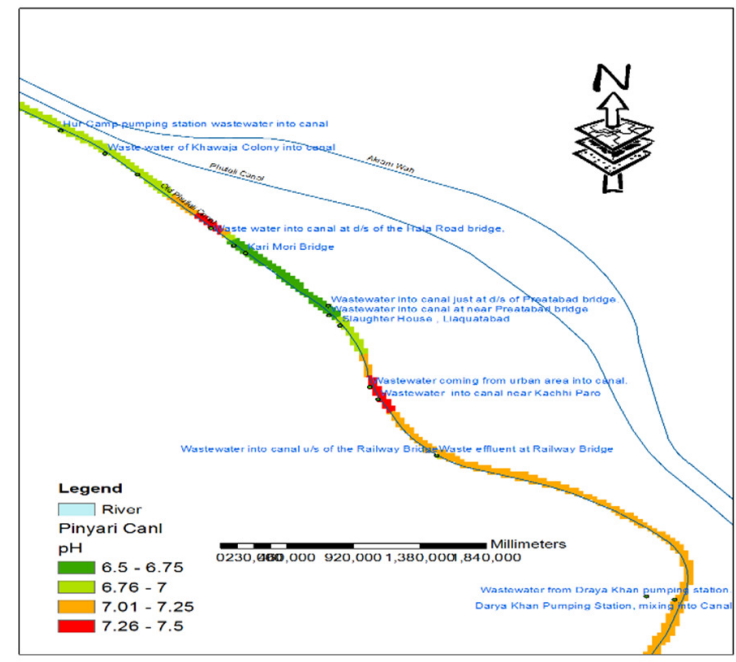

Fig. 3. Spatial distribution of $\mathrm{pH}$ with GIS

\section{2) Electrical Conductivity (EC)}

The EC of the collected samples exceeds the permissible limit of NEQS $(680 \mu \mathrm{S} / \mathrm{cm})$. The EC ranged from $760 \mu \mathrm{S} / \mathrm{cm}$ to $13700 \mu \mathrm{S} / \mathrm{cm}$. The highest value $(13700 \mu \mathrm{S} / \mathrm{cm})$ was found at location SW-1 because of wastewater that mostly comes from the domestic and saline pond area.

\section{3) Total Dissolved Solids (TDS)}

The TDS values of the collected samples are higher than the permissible limits of NEQS. The sample S-1 had the higher TDS value. Figure 5 exhibits the geospatial distribution of TDS and its red color indcates high concentration of wastewater.

\section{4) Hardness}

The hardness of all samples was higher than the limits of NEQS. The highest value was found in water Sample 1 as shown in Table III. The hardness of the collected samples varied from 120 to $760 \mathrm{mg} / \mathrm{L}$.

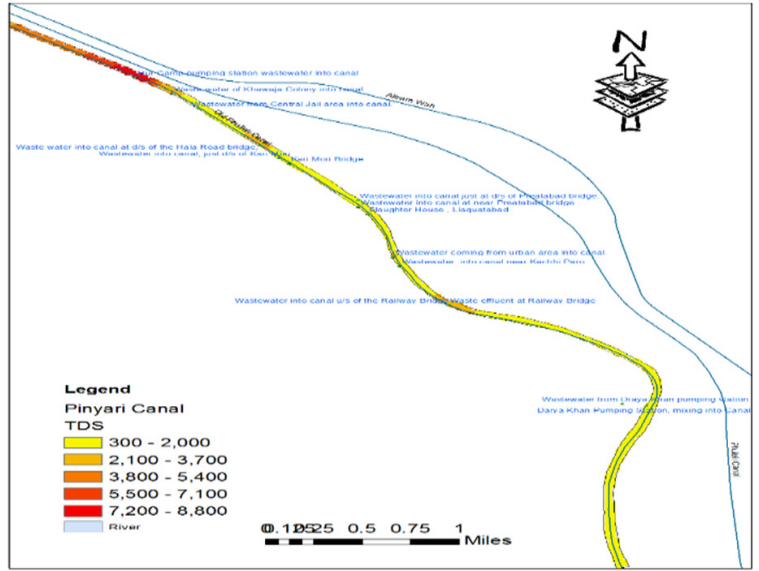

Fig. 4. Spatial distribution of TDS with GIS

\section{5) Nitrate}

The values of the collected samples shows that nitrate varied from 0.14 to $16 \mathrm{mg} / \mathrm{L}$. Nitrate level below $0.5 \mathrm{mg} / 1$ seems to have no effect on warm water fish. Water with nitrate levels exceeding $1.0 \mathrm{mg} / 1$ should not be used.

\section{6) Sodium (Na)}

The values of analyzed samples are within the permissible limit of NEQS except sample No. 14 due to the industrial unit waste. These units mostly comprise of textile, soap, paper, etc. industries, which require large quantities of sodium.

\section{7) Potassium (K)}

The analyzed result shows that the values of potassium varied from 24 to $120 \mathrm{mg} / \mathrm{L}$. The value of Sample 13 was higher than the permissible limit.

TABLE III. WATER SAMPLE PARAMETER VALUES

\begin{tabular}{|c|c|c|c|c|c|c|c|c|c|c|}
\hline Sample \# & $\mathbf{p H}$ & $\mathbf{E C}$ & $\mathbf{T D S}$ & $\mathbf{H C O}_{\mathbf{3}}$ & Hardness & $\mathbf{D O}$ & Nitrate & $\mathbf{N a}$ & $\mathbf{K}$ & $\mathbf{M g}$ \\
\hline & & $(\mu \mathrm{S} / \mathrm{cm})$ & $(\mathrm{mg} / \mathrm{L})$ & $(\mathrm{mg} / \mathrm{L})$ & $(\mathrm{mg} / \mathrm{L})$ & $(\mathrm{mg} / \mathrm{L})$ & $(\mathrm{mg} / \mathrm{L})$ & $(\mathrm{mg} / \mathrm{L})$ & $(\mathrm{mg} / \mathrm{L})$ & $(\mathrm{mg} / \mathrm{L})$ \\
\hline 1 & 7 & 13700 & 8768 & 800 & 1140 & 1.95 & 2.05 & 95 & 120 & 49.2 \\
\hline 2 & 6.9 & 3100 & 1984 & 400 & 330 & 0.29 & 0.14 & 92.3 & 38 & 40.5 \\
\hline 3 & 6.9 & 760 & 486 & 110 & 120 & 0.44 & 5.9 & 50 & 14 & 17 \\
\hline 4 & 7.5 & 4180 & 2675 & 360 & 410 & 0.56 & BDL & 92 & 101 & 44.4 \\
\hline 5 & 6.7 & 1124 & 719 & 110 & 120 & 0.34 & 1.85 & 80 & 50.6 & 24.6 \\
\hline 6 & 6.5 & 1013 & 648 & 120 & 130 & 0.45 & 0.435 & 60 & 25.2 & 20 \\
\hline 7 & 6.7 & 1290 & 826 & 180 & 150 & 0.34 & 1.425 & 90 & 37.5 & 40 \\
\hline 8 & 7.3 & 3300 & 2112 & 490 & 250 & 0.21 & 0.064 & 90.4 & 76.7 & 23.2 \\
\hline 9 & 7.3 & 1233 & 789 & 210 & 130 & 0.32 & 9.65 & 80 & 35.2 & 19 \\
\hline 10 & 6.6 & 1550 & 992 & 240 & 120 & 0.2 & 1.2 & 81.3 & 34.5 & 25.8 \\
\hline 11 & 7.2 & 1080 & 691 & 216 & 130 & 0.22 & 21.2 & 80 & 31.3 & 25.2 \\
\hline 12 & 7 & 1908 & 1220 & 250 & 210 & BDL & 4.85 & 86.3 & 48.9 & 25.7 \\
\hline 13 & 7 & 3480 & 2227 & 300 & 260 & BDL & 1.4 & 92 & 51 & 42 \\
\hline 14 & 6.9 & 3270 & 2138 & 320 & 760 & 0.8 & 12.2 & 340 & 24 & 52 \\
\hline 15 & 6.6 & 1488 & 1932 & 285 & 360 & 3.2 & 16 & 116 & 26 & 46 \\
\hline
\end{tabular}




\section{8) Magnesium (Mg)}

The values of the analyzed samples vary from 23.2 to $49.2 \mathrm{mg} / \mathrm{L}$. The maximum value found at Sample 1. Magnesium is a nutritionally essential metal that can be responsible for adverse health effects due to deficiency or excess.

\section{E. WQI Analysis}

The water quality of the study area calculated by WQI indicates that the water of most of the samples is unsuitable for drinking. The computed WQI values range from 81 to 410 as shown in Table IV. Thus, the quality of the canal water varies from very poor to unsuitable for consumption. The overall view of the WQI of the study area signifies its deteriorated water quality. Hence, the canal water is unfit for drinking during low discharge. The physicochemical parameter values of the collected samples reveal that $100 \%$ of the EC and TDS values and $70 \%$ of the $\mathrm{K}$ values were found higher than the permissible limits, while $\mathrm{pH} \mathrm{Na}$, hardness, nitrate, and $\mathrm{Mg}$ are close to the permissible limits. However, WQI indicates the water from very poor to unsuitable for drinking The result indicates that the canal is receiving different category of effluents, e.g. domestic, industrial, farming, etc. which undermine its own and ground water quality, having repercussions in agriculture, livestock, and soil while degrading the environment. There is a need to follow the ISO-14000 standard for the protection of environment from degradation. This can be achieved by adopting state-of-the-art primary and secondary wastewater treatments at tertiary level and along with the encroachment removal from the canal banks [23]. Furthermore, the use of GIS tools for monitoring of wastewater dumping sites and canal water quality is proven useful.

TABLE IV. WQI RATING

\begin{tabular}{|c|c|c|c|}
\hline Sample \# & Latitude & Longitude & WQI \\
\hline 1 & $25^{\circ} .44339$ & $68^{\circ} .37372$ & 403 \\
\hline 2 & $25^{\circ} .43706$ & $68^{\circ} .38622$ & 372 \\
\hline 3 & $25^{\circ} .40994$ & $68^{\circ} .38989$ & 209 \\
\hline 4 & $25^{\circ} .42556$ & $68^{\circ} .37939$ & 410 \\
\hline 5 & $25^{\circ} .43178$ & $68^{\circ} .38383$ & 316 \\
\hline 6 & $25^{\circ} .415$ & $68^{\circ} .39122$ & 228 \\
\hline 7 & $25^{\circ} .41822$ & $68^{\circ} .39539$ & 352 \\
\hline 8 & $25^{\circ} .40456$ & $68^{\circ} .41522$ & 389 \\
\hline 9 & $25^{\circ} .414$ & $68^{\circ} .41389$ & 344 \\
\hline 10 & $25^{\circ} .40517$ & $68^{\circ} .41078$ & 71 \\
\hline 11 & $25^{\circ} .39333$ & $68^{\circ} .41267$ & 355 \\
\hline 12 & $25^{\circ} .39372$ & $68^{\circ} .41256$ & 81 \\
\hline 13 & $25^{\circ} .40517$ & $68^{\circ} .41078$ & 86 \\
\hline 14 & $25^{\circ} .42261$ & $68^{\circ} .38033$ & 294 \\
\hline 15 & $25^{\circ} .41922$ & $68^{\circ} .400$ & 101 \\
\hline
\end{tabular}

\section{CONCLUSIONS}

The statistical analysis of physicochemical parameters showed that $\mathrm{pH}$ was within permissible limits, EC and TDS exceeded the permissible limits and hardness, $\mathrm{K}, \mathrm{Na}$, and $\mathrm{Mg}$ were almost within the permissible limits. Nevertheless the Water Quality Index showed that the water quality of the collected samples ranged from very poor to unsuitable for drinking.
The effluents discharged into the fresh canal water pose serious threats to public health, aquatic life, livestock, agriculture, soil, and ground water. Their negative impact on water may be addressed by installing primary and secondary tertiary treatment with trickling effect and oxidation ponds before it is too late [9]. It is further suggested that research studies on surface and ground water quality should continue in the area to assess canal water quality as a result of multiple categories of wastewater from different sources [1, 9, 22].

\section{ACKNOWLEDGMENT}

The authors wish to thank the Irrigation Department for providing its facilities.

\section{REFERENCES}

[1] A. A. Mahessar, S. Qureshi, A. L. Qureshi, K. Ansari, G. H. Dars, "Impact of the effluents of Hyderabad city, Tando Muhammad Khan, and Matli on Phuleli canal water", Engineering, Technology \& Applied Science Research, Vol. 10, No. 1, pp. 5281-5287, 2020

[2] Z. A. Abro, A. L. Qureshi, S. M. Kori, A. A. Mahessar, "Enhanced storage capacity and quality of Haleji and Hadero lakes connecting with Indus River for their sustainable revival", Pakistan Journal of Scientific and Industrial Research Series A: Physical Sciences, Vol. 61A, No. 1, pp. 35-42, 2018

[3] M. Kahlown, M. A. Tahir, H. Rasheed, K. P. Bhatti, Water quality status in Pakistan, Fourth Technical Report, Pakistan Council of Research in Water Resources, 2006

[4] M. A. Asghar, K. C. Mukwana, A. L. Qureshi, M. E. U. H. Leghari, A. L. Manganhar, "Assessment of water quality of LBOD system and environmental concerns", Quaid-E-Awam University Research Journal Of Engineering, Science \& Technology, Vol. 15, No. 1, pp. 32-39, 2016

[5] H. A. Shakir, J. I. Qazi, "Impact of industrial and municipal discharges on growth coefficient and condition factor of major carps from Lahore stretch of River Ravi", The Journal of Animal and Plant Sciences, Vol. 23, No. 1, pp. 167-173, 2013

[6] Unicef, The state of the world's children, Oxford University Press, 1997

[7] V. Smil, "Environmental degradation in China", Asian Survey, Vol. 20, No. 8, pp. 777-788, 1980

[8] M. A. Sohag, A. A. Mahessar, I. A. Bohio, "Pollution of Indus waters and the drainage system of Sindh", International Conference on Environmentally Sustainable Development, Islamabad, Pakistan, June 712,2004

[9] A. A. Mahessar, A. L. Qureshi, K. C. Mukwana, A. N. Laghari, "Impact of urban and industrial effluent of Hyderabad city on fresh water Pinyari canal", Quaid-E-Awam University Research Journal Of Engineering, Science \& Technology, Vol. 14, No. 2, pp. 57-63, 2015

[10] A. A. Mahessar, A. L. Qureshi, K. C. Mukwana, A. Q. Jakhrani, "Study of environmental impacts and threats to the Ramsar Haleji lake, Sindh, Pakistan", International Journal of Applied Environmental Sciences, Vol. 10, No. 5, pp. 1577-1590, 2015

[11] S. A. Baig, Q. Mahmood, B. Nawab, M. N. Shafqat, A. Pervez, "Improvement of drinking water quality by using plant biomass through household biosand filter-A decentralized approach", Ecological Engineering, Vol. 37, No. 11, pp. 1842-1848, 2011

[12] A. A. Mahessar, N. A. Memon, M. E. H. Leghari, A. L. Qureshi, G. M. Arain, "Assessment of source and quality of drinking water in coastal area of Badin, Sindh, Pakistan", IOSR Journal of Environmental Science, Toxicology and Food Technology, Vol. 9, No. 1, pp. 9-15, 2015

[13] WHO/FAO/UNCHS/UNEP Regional Workshop for the Americas on Health, Agriculture and Environmental Aspects of Wastewater Use. Jiutepec, Morelos, Mexico, 8-12, 1997, Institute Mexicano de Tecnologia de Agua (IMTA), Jiutepec, Mexico

[14] N. Kumar, A. A. Mahessar, S. A. Memon, K. Ansari, A. L. Qureshi, "Impact assessment of groundwater quality using WQI and geospatial tools: A case study of Islamkot, Tharparkar, Pakistan", Engineering, 
Technology \& Applied Science Research, Vol. 10, No. 1, pp. 52885294, 2020

[15] A. A. Mahessar, A. L. Qureshi, A. N. Leghari, S. Qureshi, S. F. Shah, F. A. Shaikh, "Impact of Hairdin, Miro Khan and Shahdad Kot drainage on Hamal Dhand, Sindh", Engineering, Technology \& Applied Science Research, Vol. 8, No. 6, pp. 3652-3656, 2018

[16] P. J. Chilton, D. Jamieson, M. S. Abid, C. J. Milne, M. E. Ince, J. A. Aziz, Pakistan water quality mapping and management project. Scoping study, Draft final report, LSHTM | WEDC, 2001

[17] M. A. Malana, M. A. Khosa, "Groundwater pollution with special focus on arsenic, Dera Ghazi Khan-Pakistan", Journal of Saudi Chemical Society, Vol. 15, No. 1, pp. 39-47, 2011

[18] S. Farid, M. K. Baloch, S. A. Ahmad, "Water pollution: Major issue in urban areas", International Journal of Water Resources and Environmental Engineering, Vol. 4, No. 3, pp. 55-65, 2012

[19] S. L. Ozesmi, M. E. Bauer, "Satellite remote sensing of wetlands", Wetlands Ecology and Management, Vol. 10, No. 5, pp. 381-402, 2002

[20] S. M. S. Noori, K. Ebrahimi, A. M. Liaghat, "Groundwater quality assessment using the water quality index and GIS in Saveh-Nobaran aquifer, Iran", Environmental Earth Sciences, Vol. 71, No. 9, pp. 38273843, 2014

[21] A. A. Mahessar, A. N. Laghari, S. Qureshi, I. A. Siming, A. L. Qureshi, F. A. Shaikh, "Environmental impact assessment of the tidal link failure and sea intrusion on Ramsar site No. 1069", Engineering, Technology \& Applied Science Research, Vol. 9, No. 3, pp. 4148-4153, 2019

[22] A. A. Mahessar, A. L. Qureshi, N. A. Memon, S. Qureshi, I. A. Bohio, "Impact assessment of effluent from Kotri industrial site area on environment: A case study", Science International, Vol. 28, No. 4, pp. $3535-3540,2016$ 